C2020. This manuscript version is made available under the CC-BY-NC-ND 4.0 license http://creativecommons.org/licenses/by-nc-nd/4.0/

\title{
Evaluating whether MPA management measures meet ecological principles for effective biodiversity protection
}

Charlotte Rachael Hopkins ${ }^{{ }^{*}}$

Neil M. Burns ${ }^{b}$

Esther Brooker ${ }^{\mathrm{c}}$

Sarah Dolman ${ }^{c, d}$

Emilie Devenport

Calum Duncan ${ }^{\mathrm{c}, \mathrm{e}}$

David M. Bailey ${ }^{f}$

\author{
*Corresponding Author \\ ${ }^{a}$ Department of Biological and Marine Science, University of Hull, UK

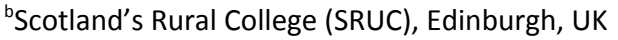 \\ 'Scottish Environment LINK (Marine Group), Perth, UK \\ ${ }^{d}$ Whale and Dolphin Conservation (WDC), Chippenham, UK \\ eMarine Conservation Society (MCS), Edinburgh, UK \\ fInstitute of Biodiversity, Animal Health and Comparative Medicine, University of Glasgow, UK
}

\begin{abstract}
Marine Protected Areas (MPAs) have been implemented as a spatial management tool throughout the world in order to meet targets for marine biodiversity conservation. The success of MPAs in achieving biodiversity conservation objectives is strongly dependent on effective management. However, evaluation frameworks for MPA management measures are often procedurally or governance focused with limited consideration of biological criteria. Here we review guiding ecological principles of MPA network design and how they can be applied to the evaluation of MPA management measures for effective biodiversity conservation. We have developed a Qualitative Statement Framework that makes recommendations for applying ecological principles to MPA management measures, using the Scottish nature conservation MPA network as a case study. Our
\end{abstract}


statements to guide MPA management measure evaluation relate to principles: representation, ecologically significant areas, rare, threatened or declining features replication, connectivity, adequacy/viability and resilience. We suggest that using the ecological principles for MPA design in management measure evaluation addresses a gap in current management evaluation tools. This approach would be particularly useful in situations where management measures are applied to MPAs post-designation and where MPAs are managed as zoned or multi-use sites. Future MPA management evaluations should incorporate criteria to demonstrate how management measures meet each of the ecological principles.

Key Words: MPA management, marine protected area network, Scotland, OSPAR, ecological principles

\section{Introduction}

Following adoption of several international biodiversity conservation agreements, many countries have come under pressure to create networks of MPAs. As biodiversity conservation is the ostensible reason for their designation it has been common for biodiversity criteria and ecological principles to be used in site selection (e.g Australia, Environment Australia 2003, Scotland, Scottish Government 2011a, Canada, Government of Canada 2014). MPA designation does not equate to protection and at some point within the MPA implementation process, a policy decision is required on what level of protection to give to sites or zones within the sites. In attempting to also meet socio-economic objectives (including achieving fisheries targets) MPA management, in this context the measures in place that dictate the level of protection, may shift from applying the original biodiversity criteria and ecological principles. This shift can result in the weakening of the effectiveness of MPAs to conserve biodiversity (Klein et al. 2008). MPAs with the overall primary objective to conserve biodiversity cannot be considered successful unless they achieve this biological objective (Agardy et al. 2011, Fox et al. 2012, Roberts et al. 2018).

Here, we suggest a return to the guiding ecological principles for MPA networks that have the primary objective of biodiversity conservation, reviewing how these principles translate into MPA management. We have compared ecological principles across guidance from the Convention of Biological Diversity (CBD), the IUCN World Commission on Protected Areas (IUCN-WCPA) and the Oslo Paris Convention for the Protection of the Marine Environment of the North-East Atlantic (OSPAR). We have reviewed how MPA sites can be selected using the OSPAR principles for the development of an ecologically coherent network, and we present a novel framework for evaluating 
how these principles of MPA network design can be applied in the selection of MPA management measures. We use the Scottish Nature Conservation MPA (ncMPA) network as an illustrative case study for an initial application of this framework. We present a discussion of our findings in the context of achieving effective biodiversity conservation across an MPA network.

\subsection{Principles for an Ecologically Coherent Network}

To meet broad scale conservation objectives of protecting wider ecosystems, single, isolated MPAs designed and implemented in an ad-hoc manner, have been found deficient (Agardy et al. 2011). Networks of MPAs have a greater potential than individual MPAs to achieve conservation and wider ecological benefits and are widely advocated over single MPAs to address the plethora of threats facing the marine environment (Allison et al. 2003, Keller et al. 2009, Burt et al. 2014). Networks of MPAs that are well-designed and well-managed can sustain species, habitats and ecological processes across a larger geographic scale and therefore deliver on some principles of Ecosystem Based Management (EBM) (e.g. reducing cumulative impacts that compromise the delivery of ecosystem services) (Halpern et al. 2010). However, a lack of systematic conservation planning for MPA networks can lead to gaps in protection (Mora et al. 2006, Critchley et al. 2018, Fischer et al. 2018). Additionally, while MPA networks are preferable and have been widely implemented, judging whether the individual MPA sites form a coherent network remains a challenging task (Johnson et al. 2014).

The OSPAR Commission developed guidance on developing an ecologically coherent network (OSPAR Commission 2006), which aims to protect and conserve ecosystems and biological diversity, and restore areas that have been adversely affected (Table 1). The CBD COP9 (2008) adopted scientific guidance for selecting areas to establish representative networks of MPAs, including in the open ocean and deep-sea habitats (COP9/20 Annex 2). IUCN- WCPA provided a knowledge synthesis regarding designing effective MPA networks that are resilient to human and environmental threats (IUCN-WCPA 2008). Together this guidance, from OSPAR, the CBD and IUCN-WCPA, specifies that MPA networks should encompass replicated areas, representative of the species, habitats and ecosystems (including ecological processes) in a region and that the areas are ecologically connected. The core concept of an ecologically coherent network is that the constituent MPAs maintain a relationship to one another and to the surrounding environment (Smith et al. 2009).

Table 1. Aims of the OSPAR ecologically coherent network of Marine Protected Areas (MPAs). 
a. protect, conserve and restore species, habitats and ecological process which are adversely affected as a result of human activities

b. prevent degradation of and damage to species, habitats and ecological processes, following the precautionary principle

c. protect and conserve areas that best represent the range of species, habitats and ecological processes in the OSPAR area

Characteristics of an ecologically coherent network

1. A network's constituent parts should firstly be identified on the basis of criteria which aim to support the purpose of the network.

2. The development of an ecologically coherent network of MPAs should take account of the relationships and interactions between marine species and their environment both in the establishment of its purpose and in the criteria by which the constituent elements are identified.

3. A functioning ecologically coherent network of MPAs should interact with, and support, the wider environment as well as other MPAs although this is dependent on appropriate management to support good ecosystem health and function within and outside the MPAs.

The guiding ecological principles are intended to mitigate and reduce risk across the seascape thereby promoting resilience and increasing the likelihood that conservation objectives are achieved. However, achieving ecological coherence in the design of an MPA network should not be the intended end point. Ultimately, effective management that maintains the ecological structure and function of protected sites is needed to secure conservation objectives (Allison et al. 2003, Johnson et al. 2014). We therefore argue that the ecological principles should also apply to both MPA network design and MPA management measures if the conservation goals are to be realised.

\subsection{Evaluating MPA Management}

MPA designation alone is unlikely to reduce the presence of human pressure in the designated area. MPA implementation must be accompanied by effective management and regulations which address threats to biodiversity (Zupan et al. 2018). These management measures should be directed towards reducing or eliminating threats that would prevent achieving the principle biodiversity conservation objectives (Zupan et al. 2018). The achievement of these conservation objectives is dependent on many elements including MPA design, the broader context within which they are situated and their broader management encompassing governance and resource availability (Gill et 
al. 2017). Edgar et al. (2014) demonstrate that conservation benefits increase with the accumulation of five key features: large $\left(>100 \mathrm{~km}^{2}\right)$, no-take, enforced, older and isolated. However, few MPAs are likely to comprise all five features. For example, while coastal MPAs are likely to be well enforced they are seldom also isolated.

Overall, there is considerable uncertainty surrounding when and where MPAs are the most effective in achieving biological outcomes (Woodcock et al. 2016). It is difficult to define a single best way to evaluate MPA management effectiveness (Wu et al. 2015) and as a result many methods have been proposed. As part of MPA management effectiveness evaluation, a number of indicator frameworks have been proposed (e.g. Pomeroy et al. 2005, Pajaro et al. 2010, Gallacher et al. 2016). Indicators of progress are intended to show how well MPA management is working relative to its objectives (Pajaro et al. 2010). These indicators can include biophysical, governance and socioeconomic components. As MPAs are ultimately a tool for conserving biodiversity and ecological processes, biophysical indicators are of primary importance in evaluating MPA effectiveness (Pomeroy et al. 2005).

Focal species abundance and population structure, and habitat extent are seen as more accurate determinants of whether species and habitat conservation and/or recovery is effective within the MPA and appear in multiple indicator frameworks (Batista et al. 2015, Gallacher et al. 2016). However, biophysical indicators are usually targeted at post - implementation evaluation and are dependent on a robust baseline, requiring large amounts of monitoring data that are often lacking. A qualitative statement framework approach tailored to ecological design principles may aid in the identification and evaluation of proposed or recently implemented management measures in the absence of robust baseline information or post-implementation monitoring data. This builds on current scorecard evaluation approaches, which are recommended in the absence of ecological monitoring data but are often be heavily weighted towards procedural, governance and socio-economic aspects of MPA processes (e.g. World Bank MPA scorecard (Staub and Hatziolos 2004), OSPAR scorecard (OSPAR 2007)). While good governance and positive socioeconomic factors are critically important to MPA success, ultimately the health of marine biodiversity should be the defining success factor where the objective is to protect marine biodiversity. Where we have identified a gap in evaluation approaches is early on in the MPA process, in the selection of management measures that follow ecological design principles. This evaluation step is essential as it is not practical to delay an assessment of management effectiveness until detailed post implementation data can be collected (Batista et al. 2015). 
Our proposed framework is intended to enable the review of management measures in the context of guiding ecological principles for MPA network design to see if management measures are consistent with these principles. This qualitative framework is not intended to replace more detailed quantitative assessments but can aid in the evaluation of MPA management measures towards achieving biological outcomes where data is lacking for example, as part of an a priori approach.

\section{Methods}

\subsection{Proposed Qualitative Statement Framework to evaluate MPA management}

The CBD (CBD 2008), IUCN-WCPA (IUCN-WCPA 2008) and OSPAR (OSPAR Commission 2006) published guidance on the principles for designing an ecologically coherent MPA network. For this study we rationalised the different terminology relating to the ecological principles presented in the guidance documents (Figure 1). We then used this analysis to enable the extraction of a set of common ecological principles for MPA design (defined in Table 2.). Each of the six resultant common ecological principles were expanded into a group of qualitative statements indicating recommendations for how management measures should meet each principle. These qualitative statements were developed by reviewing the guidance for each principle in detail and determining how management measures should support delivery of the principle. An iterative discussion process among the authors resulted in the final selection of the statements in the proposed Qualitative Statement framework.

\subsection{Application of the Qualitative Statement Framework to Scotland's nature conservation MPA (ncMPA) Network}

We have used the Scottish ncMPA network as a case study to provide a preliminary test of the suitability of our proposed Qualitative Statement framework. The main objective of this preliminary review was to see whether the management measures in the case study could be evaluated using these statements and how well the management measures of the Scottish ncMPA network align with common ecological principles. This was achieved by collating and reviewing policy documentation from the Scottish ncMPA process on the selection of the ncMPA sites.. Policy documents for the Scottish ncMPA process were sourced from freely available material produced by Scottish Natural Heritage (SNH), Joint Nature Conservation Committee (JNCC) and Marine Scotland (Appendix A). We discuss our review of the policy documentation for the Scottish ncMPA process against our Qualitative Statement Framework in section 3.3. 
Scotland's Nature Conservation MPA (ncMPA) network is a good model for testing the application of ecological principles to management as i) ncMPA sites were selected using principles related to OSPAR guidance for the development of an ecologically coherent network ii) progress towards achieving the conservation objectives of Scotland's ncMPA network has recently been reviewed (2018) and iii) management measures have been implemented for some sites, yet other ncMPA sites are without management measures. Therefore, reviewing management measures that have been implemented could immediately lead to improvements in the choice of management measures for those ncMPA sites without implemented measures.

\subsubsection{Scotland's ncMPA Management}

Following designation of 30 ncMPAs in July 2014, ncMPAs were split into groups to allow for phased implementation of fisheries management measures. A prioritisation document details the groupings of the phased implementation, covering the 17 inshore ncMPAs and 25 Special Areas of Conservation (SACS) (Marine Scotland 2014). The sites were prioritised generally on the presence of the most sensitive benthic habitats and species. The first phase of measures was proposed in 2014 through a series of stakeholder workshops followed by formal public consultation. The post-consultation revised measures were agreed by Scottish ministers and adopted into statutory force in 2016. Similar processes are currently underway for a second phase of inshore ncMPAs and SACs and offshore sites. Proposed fisheries measures for offshore ncMPAs and SACs must be signed off by European Member States and the European Commission. As a result, 12 ncMPAs (all inshore) have implemented management measures to date. Licensed developments and other marine activities are managed through other legislative mechanisms and therefore have limited integration with the fisheries measures implemented across the network.

\section{Results}

\subsection{Comparison of ecological principles for MPA network design}

A comparison of the ecological principles for MPA networks shows clear overlap between guidance developed by the CBD, IUCN-WCPA and OSPAR (Figure 1). We identified six core principles of MPA network design across the different sets of guidance: representation, concept for selecting areas (e.g. features, ecologically significant areas), connectivity, replication and adequacy/viability. 
Ecologically and

biologically

Ecologically

significant areas

significant areas

Features

$\mathrm{F} \epsilon$

Representativity

Representation

Representativity

Repre

Connectivity
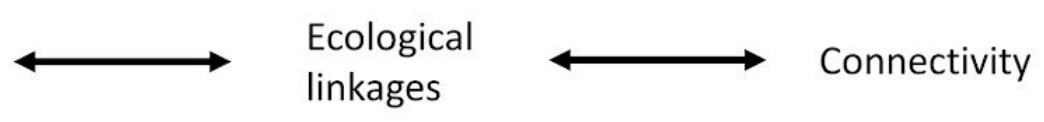

$\mathrm{Li}$

Replicated

ecological

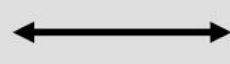

Replication

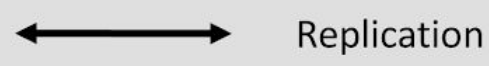

Replication

$\operatorname{Re}$

features

Adequate and

viable sites

Size, shape and

spacing of the

$\leftrightarrow$ Size of site

$\mathrm{Ge}$

MPAs

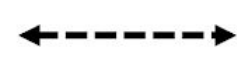

ran

var

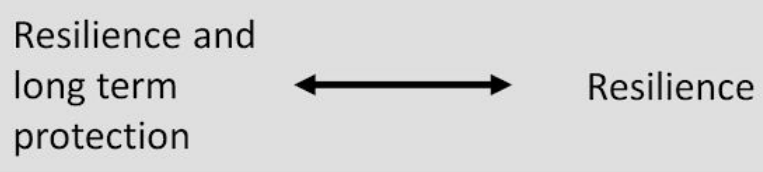

Resilience and

long term

Resilience

$\mathrm{Re}$

Figure 1. Relationship between the CBD, IUCN, OSPAR and Scottish ncMPA guiding ecological principles for MPA network design (adapted from Smith et al. 2009). Solid arrows indicate equivalent concepts, dashed arrows indicate related concepts. ${ }^{1}$ (CBD 2008) ${ }^{2}$ (IUCN-WCPA 2008) ${ }^{3}$ (OSPAR Commission 2006) ${ }^{4}$ (Scottish Government 2011b)

\subsection{Qualitative Statement Framework for applying ecological principles to management measures}

Table 2 presents a Qualitative Statement framework for evaluating to what extent the ecological principles have been applied to MPA management measures.

Table 2. Qualitative statement framework for evaluating how MPA network management measures meet guiding ecological principles

Principles and qualitative statements for management criteria

Principle 1: Representation - Protect the full range of biodiversity and associated oceanographic environment

Management Measure Criteria 
1.1 All protected features are represented by appropriate management measures

1.2 Management measures seek to address all key threats to protected features individually and cumulatively

1.3 All protected features present in MPAs should have a conservation objective so appropriate management measures can be implemented

1.4 Characteristic or component species of a habitat or large-scale feature are protected explicitly through management measures

Principle 2: Concept for selection - ecologically significant areas, rare, threatened or declining features Protect areas, species and habitats of unique value, high functional importance or vulnerable areas Management Measure Criteria

2.1 Features of ecological significance or conservation concern receive greater protection

2.2 Management measures are applied to good and poor examples of feature condition across the network allowing for conservation and recovery reflecting the conservation status of the feature

2.3 Species and habitats that are under threat and/or declining have management measures that promote recovery

2.4 Management measures are proportionate to the conservation status of the feature, and precautionary where data are lacking

Principle 3: Connectivity - Ensure MPA sites are ecologically connected within the network Management Measure Criteria

3.1 Genetic diversity and viability of features are protected under management measures in different geographical areas

3.2 Management measures protect ecological connections e.g. protection of key prey items for mobile species

3.3 Management measures protect key life stage areas for mobile species within the site for which it is designated

Principle 4: Replication - Provide replicates of all habitats and species protected to spread the risk of negative impacts across the bioregion

Management Measure Criteria

4.1 Each replicate is accompanied by effective management measures across the biogeographic range and relate to the features' conservation priorities and life history needs

4.2 Management measures are consistent relative to impacting activity on the feature across replicates within the network

Principle 5: Adequacy and viability - Ensure the size and shape of sites within the network are optimum to encompass ecological processes and maintain population integrity

Management Measure Criteria

5.1 Appropriate size of a management measure zone should be determined by the purpose of the management (e.g. conserve or recover) and be sufficiently large to maintain the integrity of the feature 5.2 Management area has a buffer zone that reflects the "conservation status" of the feature 
5.3 Buffer zone is proportionate to the type of impact and seabed conditions, and the risk of impact to feature

5.4 Edge effects are minimised through appropriate size and shape of management zones (simple boundaries, straight lines, use of landmarks)

Principle 6: Resilience - Increase the resilience of desirable ecosystem states in the face of stressors (natural and anthropogenic)

\section{Management Measure Criteria}

6.1 Management measures across the whole network are adequate to protect and recover features

6.2 Management measures supports ecosystem health and function within and outside the MPAs, delivering wider ecosystem function/services

6.3 Management measures take account of climate change and changing environmental conditions and is precautionary where data is lacking

6.4 Management measures protect areas of high use as well as already minimally impacted areas

6.5 Management of the site and network as a whole allows for scientific reference areas and robust monitoring

\subsection{Scottish ncMPA network case study evaluation using Qualitative Statement Framework}

The following six sections discuss how the ecological principles should be applied to MPA management measures in our Qualitative Statement Framework (Table 2.) using illustrative examples from the Scottish ncMPA network.

1. Ecologically significant areas or features. There are related concepts in the CBD, IUCN-WCPA and OSPAR guidance for selecting sites. One approach is to choose areas based on habitats containing several key biodiversity elements (e.g., rare habitats, high-quality habitats, areas with multiple contiguous habitats). By protecting a diverse array of habitat types, this should conserve ecological processes and ecosystem integrity (IUCN-WCPA 2008). The OSPAR guidance is focused around a feature-based approach, whereby "a feature is the specific aspect(s) of interest (i.e. its biodiversity or ecological character) for which a site is designated" (OSPAR Commission 2006). However, this approach is problematic in terms of management if the feature is reduced to a particular species or habitat rather than an ecological process or biodiversity (more akin to the CBD and IUCN Ecologically Biologically Significant Areas (ESBA)). Management measures for Scottish ncMPAs were developed based on the assessment tool FEAST (Feature Activity Sensitivity Tool) (Marine Scotland 2013), an evidence-based approach to identifying the impacts that multiple marine activities and pressures have on different protected features. This approach does not consider the site as a whole, or as an 
EBSA whereby interactions between pressures, cumulative impacts and the relative contribution of each pressure would need to be managed (Dunstan et al. 2016).

In the Scottish ncMPA network, 23 individual habitat features are represented within the network and 7 individual species are represented as designated features (not including replicates) (Appendix A). Of these species and habitats, 10 are present on the OSPAR threatened and declining list. Management of these species arguably requires consideration of not only direct impacts from pressures, but management measures that maintain ecosystem links and aids their recovery. Our framework proposes management measure criteria that for rare, threatened/declining species, should ensure stricter protection to enable recovery and be precautionary where data are lacking.

2. Representative. MPA networks should provide adequate representation of species and habitats across the sites within the network (McLeod et al. 2009, Gaines et al. 2010, Burt et al. 2014). Representation of species and habitats within an MPA network should only be considered adequate if accompanied by management of key threats (Zupan et al. 2018). Our framework proposes that to evaluate whether representativity has been met in terms of management measures, evaluation criteria should include whether threats have been considered both individually and cumulatively (Criteria: 1.2). However, the Scottish ncMPAs management measures assessment tool FEAST, does not account for intensity, frequency or cumulative impacts of pressures at a site level. Licensed developments (e.g. renewable energy, oil and gas) and other marine activities are managed through other legislative mechanisms and therefore have limited integration with the fisheries measures implemented across the network.

A key logical argument made in the defence of refined representation to a few key species and habitats is that by protecting these features, incidental protection for other species and habitats will be achieved. This concept of "umbrella species" is most often applied to species with a critical ecological function, large range or complex habitat requirements (Kalinkat et al. 2017). Marine mammals may act as umbrella species and therefore designing an MPA based around them may benefit other species (Hoyt 2008). However, if management measures for mobile species within the Scottish ncMPA network only address direct impacts (i.e. bycatch, entanglement), the measures may have little benefit to other species and habitats. The achievement of conservation objectives will be further hindered for marine mammals if management measures do not address issues relating to prey depletion and habitat loss. Overall the wider ecosystem enhancement that could be achieved by establishing effective management measures for marine mammals is likely to be low.

3. Connectivity. Connectivity can be understood as the ecological linkages between and within individual MPAs. These linkages include: movements of animals from one site to another; larval 
dispersal and settlement; and connections between adjacent or continuous habitat. Design of an MPA may consider habitat use within the life cycle of a species, the IUCN-WCPA guidance specifically references "contiguous habitat systems and adjacent habitats tightly linked through the flow of matter, energy and organisms" as an important consideration in network design (IUCN-WCPA 2008). Management using a feature-based approach, as in the Scottish ncMPA network, is unlikely to consider functionally linked habitats across a landscape. Our proposed framework includes criteria for management measures that consider the wider landscape connections (Criteria: $3.2 ; 3.3$ ). It is important that an ecosystem-based approach to management is used that does not manage habitat or key life-stage areas in isolation, but holistically considers the wider trophic and ecosystem links and considers cumulative impacts of other human pressures (Leary et al. 2018).

OSPAR guidance is clear that assessments of connectivity should not delay the selection of sites to form an ecologically coherent network, allowing for the knowledge that data to inform these assessments is usually lacking. Although progress in assessing connectivity between MPAs is evident in recent publications (Fox et al. 2016, Foster et al. 2017), without a clear understanding of species demographics, it is not obvious how much connectivity is enough. OSPAR guidance also states that in terms of connectivity, offshore areas may be larger and further apart to encompass larger scale processes. In Scotland, the largest ncMPAs are situated offshore, in line with OSPAR guidance. However, without a clear assessment of biodiversity distribution, pressures and management effectiveness in dealing with these pressures, it is not possible to evaluate the level of connectivity between MPA sites, which is necessary to assess whether the MPAs function as a network (Krueck et al. 2017).

4. Replication. In terms of the replication principle, we propose that MPA management should be consistent relative to the impacting activity on the feature across replicates within a network (Criteria: 4.1; 4.2). While this seems to have been applied more consistently with fisheries measures in the Scottish ncMPA sites, variability exists in aquaculture licensing across MPA sites. Planning permission for aquaculture sites is granted by the local Planning Authority and there is some contention about the degree to which inshore sites are adequately protected from licensed activities such as aquaculture (Pautz et al. 2019).

5. Adequacy and viability. The adequacy and viability of sites to protect biodiversity incorporates considerations of site size, shape and spacing. The boundaries of ncMPAs were drawn "as closely as possible around the feature(s)" (Scottish Government 2011b). The same is also true for the boundaries of management measure zones within the ncMPAs, whereby management measure zone boundaries are designed as complex shapes, tied closely to the feature extent (Scottish 
Government 2011b). The complexity of management measure zone shapes is counter to scientific advice that recommends simple, enforceable boundaries. This approach does not allow for appropriately sized buffer zones that allow for expansion, recovery and precautionary management of a feature, particularly in cases where a feature may be vulnerable to impacts from climate change or in the case of a species-feature, which would require suitable habitat to recover into. The complexity of management measure zone shapes also increases the edge effects of the zones raising questions over the long-term viability of the sites (Bobiles and Nakamura 2019).

6. Resilience. A key guideline from the IUCN-WCPA guidance in developing an MPA network, is the requirement for long term protection, and the understanding that no-take areas provide the greatest ecological benefit (IUCN-WCPA 2008). Incorporating these strictly protected areas is considered a foundation in most networks and a key element in ensuring resilience, the area under strict protection varying depending upon the recovery being sought and level of decline.

There is a clear indication from scientific literature that multi-use MPAs have fewer ecological benefits, and the significant proportion of Scottish ncMPAs within these lower protection categories are a cause for concern regarding the long-term capacity of the Scottish MPA network to conserve marine biodiversity. At a site level, the whole of the Scottish MPA network is designated as multi-use, variably permitting different fishing methods and human activities across the network. There are only are two small strictly protected areas within two ncMPA sites of the Scottish ncMPA network. Loch Teacuis, within the Loch Sunart to the Sound of Jura MPA has a prohibition on dredge, beam and demersal trawl, demersal seine net, set nets, lines, long lining, creels and fishing for horse mussels $\left(1.05 \mathrm{~km}^{2}\right)$. North Lamlash Bay within the South Arran MPA, is the only true no take marine reserve where all forms of fishing activity are prohibited $\left(2.66 \mathrm{~km}^{2}\right)$.

The Scottish Marine Atlas summarised the state of Scottish marine biodiversity prior to the designation of the ncMPAs; the majority of shelf and deep sea habitats, and many species were in decline (Baxter et al. 2011). The ecological baseline established with the Scottish Marine Atlas is now the baseline against which subsequent policy interventions are measured, but it is a baseline of an already declining and heavily impacted marine environment. Of the 127 designated features (including replicates: Appendix A), only 4 designated features (all habitat) have a conservation objective of recover. Resilience under OSPAR guidance is "the ability an ecosystem to recover from disturbances within a reasonable timeframe" (OSPAR Commission 2006) and recovery of the marine environment is to be achieved through the use of MPAs (OSPAR Commission 2006). Yet the limited number of recover objectives within Scottish ncMPA network seem unambitious in the context of a diminished marine environment. Furthermore, by drawing management measure boundaries tightly 
to the known extent of features, even given the diminished status compared to historical accounts, the network itself has not been designed with the recovery of features in mind. With management measures delineated on known feature presence, against an already diminished baseline, there is little room for recovery or range expansion and a greater risk of damage to the feature (Hopkins et al. 2016).

\section{Discussion}

This study was designed to provide a framework for evaluating the suitability of MPA management measures established for an MPA network that has biodiversity conservation as its primary objective. While our proposed framework does not address wider management effectiveness factors such as lack of resources and political will, which limit the implementation of systematic MPA evaluation, our proposed framework develops criteria that embeds the ecological principles for good MPA network design in the selection and implementation of management measures (Table 2). We identified a gap between MPA network design that follows guiding ecological principles and the application of these principles to MPA management measures. With growing concerns that MPAs are not truly protected, as they allow significant extractive activities that undermine biodiversity conservation (Sala et al. 2018), the need for an evaluation framework that links management measures to biological criteria is critical.

Across the guidance of the CBD, IUCN-WCPA and OSPAR for designing an ecologically coherent network, there is clear overlap and agreement on which principles constitute good design (Figure 1.). There are examples of assessing MPA network design against these principles (notably Ban et al., (2014)). However, missing from these analyses is a clear link between the ecological principles and the management measures implemented in the MPA. This could be due to differences in MPA process. For example, some MPAs are implemented with management measures, i.e. the site is chosen as a fully-protected no-take reserve, or a multi-use area as part of a wider network, or the site is designated as an MPA but without any management measures. This latter category of MPA is problematic as without management the site could become a "paper park" with no meaningful contribution towards biodiversity conservation.

MPA sites may take a zoned approach to implementing management measures, varying protection levels within the site, allowing for multi-use. Our framework particularly targets areas where management measures may be variable across the sites, as in the case of the Scottish ncMPA sites which are intended for multi-use. Our concern is that a site may be designed as part of a network to follow the ecological principles of good design, but by dividing the site into different management zones, the ecological principles are no longer applied effectively. 
There is a worrying lack of MPA management effectiveness data worldwide, resulting in an inability to determine whether legal MPA designation equals genuine biodiversity protection (Roberts et al. 2018, Sala et al. 2018). Currently, it is difficult to provide systematic evaluations of management effectiveness across MPA networks. Without monitoring data to inform indicator targets on the status of species and habitats within the MPA sites, these assessments are reliant on either expert judgement or the often incomplete survey information that contributed to the selection of sites. The most commonly used protected area management effectiveness frameworks are those with an emphasis on the management process (Pyhälä et al. 2019). Most of these tools lack any assessment of the state of biodiversity or do not relate management effectiveness to conservation outcomes (Coad et al. 2015, Pyhälä et al. 2019). There is a clear link between effective MPA management performance (e.g. appropriate resources) and the achievement of ecological outcomes (Gill et al. 2017). However, within assessment tools there is little to link what may seem good management, a documented management plan and inclusion of stakeholders, which are elements of good governance, to biological processes occurring within an MPA. The impression of a well-managed network could therefore be achieved with little evidence or evaluation of achieving conservation outcomes.

While the procedural aspects of the Scottish ncMPA process for implementing management measures may score highly using tools such as the OSPAR scorecard tool (OSPAR 2007), the framework currently available for evaluating management effectiveness, a comprehensive assessment of the ecological effectiveness of management, is lacking. Adaptive management is situated within the Scottish ncMPA monitoring strategy (Marine Scotland 2017), but this needs to be based on a large amount of monitoring data to inform decision making. A risk-based approach to designing a monitoring strategy for the Scottish ncMPA network has been used with no quantitative indicators to measure what constitutes success in achieving the conservation objectives.

MPA effectiveness in ecological terms is usually measured through comparing biological indicators (sizes of organisms, density and biomass of fish assemblages, species richness and live cover of benthic organisms), to baseline information prior to MPA establishment and adjacent unprotected areas (Giakoumi et al. 2018). However, the appropriate rigour of design for these evaluations is often lacking (Giakoumi et al. 2018) and the variability in activities permitted in multi-use MPAs, will make it difficult to estimate their value in protecting biodiversity, especially in the absence of site monitoring. A mechanism for rigorous site monitoring exists in Demonstration and Research MPAs within the Scottish ncMPA process, but using these sites to enable performance assessment would need to be built into the long-term management of the MPA network. 
Using frameworks that rely on qualitative judgements only are unlikely to provide an accurate evaluation of the effectiveness of MPA management. For example, in the preliminary review of Scotland's ncMPA network, our method of collating the species and habitats listed as designated features within official documents is limited in determining what constitutes adequate representation and replication of these features across the network. This method, used elsewhere, does not consider the absolute areas of habitats or sizes of populations contained within ncMPAs and therefore is it difficult to ascertain whether the long term sustainability will be achieved (Rees et al. 2018). We recommend that our proposed framework is used as a complimentary tool for MPA evaluations, but that it is does not replace more quantitative assessments and long-term monitoring of MPA networks. A further development of our proposed qualitative statement framework could be further consultation of the qualitative statements with MPA managers or to include a scoring system to be trialled with a panel of stakeholders in the structured evaluation of an MPA network.

\section{Conclusions}

Current assessments of progress towards achieving marine biodiversity conservation objectives are reliant on MPA area coverage targets, and although there have been substantial increases in marine area under "protection", there are persistent declines and degradation of marine species and habitats. Therefore, evaluating MPA management is critically important in assessing how effective MPAs are in conserving and recovering marine ecosystems. This study proposes a novel Qualitative Statement framework against which to evaluate how guiding ecological principles of network design are being applied to the MPA management measures. We have highlighted a gap in current management evaluation tools that are often procedurally focused and lack clear emphasis on ecological principles that must be applied to achieve conservation objectives.

Our framework is not a substitute for rigorous quantitative assessments of MPA management towards biological indicators and targets. Unfortunately, owing to budgetary constraints in protected area processes, data collection post-implementation that is required for assessments of management effectiveness, is unlikely to be prioritised and when data is collected, it is often ad-hoc and un co-ordinated (Geldmann et al. 2018). The framework proposed here is therefore likely to be useful where data is lacking, as it provides a structure for qualitative judgements to inform evaluations of MPA management plan suitability. The framework could help guide stakeholder evaluations of MPA management measures through workshops and focus groups, where experience and local knowledge can be used to evaluate the extent to which the ecological principles have been applied in local MPA management measures. In comparison to time critical, expensive quantitative 
data gathering, qualitative evaluations like these are more achievable because they are less expensive, can produce evaluations retrospectively and rapidly elicit results. When quantitative data is available, we suggest using our framework in combination with biological indicator frameworks to verify changes occurring as a result of MPA management.

Furthermore, our framework is particularly applicable in situations where management measures are applied to MPAs post-designation and where MPAs are managed as zoned or multi-use sites. This is because if management measures are not applied at the same time as the ecological principles to inform MPA network design, there may be a drift from these principles, resulting in less effective MPA sites. In cases where biodiversity conservation is the primary objective, this framework is also especially useful as it focuses on ecological principles rather than governance or procedural aspects that may result in a higher weighting towards socio-economic considerations. In the case of the Scottish ncMPA network, a preliminary application of the framework indicates ecological principles have been applied in the selection of ncMPA sites, but that by dividing MPAs into different management zones, some of these principles may have been weakened. Future MPA management evaluations should incorporate criteria to demonstrate how management measures meet each of the ecological principles for MPA network design.

\section{Acknowledgements}

This study was funded by Scottish Environment LINK. The views expressed in this paper are not necessarily representative of the collective view of Scottish Environment LINK's Marine Group, nor of individual member bodies.

\section{Appendix A. Supplementary information}

\section{References}

Agardy, T., G. N. di Sciara, and P. Christie. 2011. Mind the gap: Addressing the shortcomings of marine protected areas through large scale marine spatial planning. Marine Policy 35:226-232.

Allison, G. W., S. D. Gaines, J. Lubchenco, and H. P. Possingham. 2003. Ensuring Persistence of Marine Reserves: Catastrophes Require Adopting an Insurance Factor. Ecological Applications $13: 8-24$. 
Ban, N. C., C. McDougall, M. Beck, A. K. Salomon, and K. Cripps. 2014. Applying empirical estimates of marine protected area effectiveness to assess conservation plans in British Columbia, Canada. Biological Conservation 180:134-148.

Batista, M. I., S. Henriques, M. P. Pais, and H. N. Cabral. 2015. A framework for the assessment of MPA effectiveness based on life history of fishes. Ocean and Coastal Management 118:75-87.

Baxter, J. M., I. L. Boyd, M. Cox, A. E. Donald, S. J. Malcolm, H. Miles, B. Miller, and (Editors) Moffat, C.F. 2011. Scotland's Marine Atlas: Information for the national marine plan. Page Marine Scotland Edinburgh.

Bobiles, R. U., and Y. Nakamura. 2019. Partially protected marine areas as a conservation tool for commercially important fishes in the Philippines: Do age, size, and design matter? Regional Studies in Marine Science 25:100459.

Burt, J. M., P. Akins, E. Latham, M. Beck, A. K. Salomon, and N. C. Ban. 2014. Marine protected area network design features that support resilient human-ocean systems - Applications for British Columbia, Canada.

CBD. 2008. Decisions adopted by the Conference of the Parties to the Convention on Biological Diversity at its ninth meeting. UNEP/CBD/COP/9/Decision IX/20.

Coad, L., F. Leverington, K. Knights, J. Geldmann, A. Eassom, V. Kapos, N. Kingston, M. de Lima, C. Zamora, I. Cuardros, C. Nolte, N. D. Burgess, and M. Hockings. 2015. Measuring impact of protected area management interventions: current and future use of the Global Database of Protected Area Management Effectiveness. Philosophical Transactions of the Royal Society B: Biological Sciences 370:20140281.

Critchley, E. J., W. J. Grecian, A. Kane, M. J. Jessopp, and J. L. Quinn. 2018. Marine protected areas show low overlap with projected distributions of seabird populations in Britain and Ireland. Biological Conservation 224:309-317.

Dunstan, P. K., N. J. Bax, J. M. Dambacher, K. R. Hayes, P. T. Hedge, D. C. Smith, and A. D. M. Smith. 2016. Using ecologically or biologically significant marine areas (EBSAs) to implement marine spatial planning. Ocean and Coastal Management 121:116-127.

Edgar, G. J., R. D. Stuart-Smith, T. J. Willis, S. Kininmonth, S. C. Baker, S. Banks, N. S. Barrett, M. A. Becerro, A. T. F. Bernard, J. Berkhout, C. D. Buxton, S. J. Campbell, A. T. Cooper, M. Davey, S. C. Edgar, G. Försterra, D. E. Galván, A. J. Irigoyen, D. J. Kushner, R. Moura, P. E. Parnell, N. T. Shears, G. Soler, E. M. A. Strain, and R. J. Thomson. 2014. Global conservation outcomes 
depend on marine protected areas with five key features. Nature 506:216-20.

Environment Australia. 2003. Australia's Marine Protected Areas: Protecting our coasts and oceans.

Fischer, A., D. Bhakta, M. Macmillan-lawler, and P. Harris. 2018. Existing global marine protected area network is not representative or comprehensive measured against sea fl oor geomorphic features and benthic habitats. Ocean and Coastal Management 167:176-187.

Foster, N. L., S. Rees, O. Langmead, C. Griffiths, J. Oates, and M. J. Attrill. 2017. Assessing the ecological coherence of a marine protected area network in the Celtic Seas. Ecosphere 8:e01688.

Fox, A. D., L. Henry, D. W. Corne, and J. M. Roberts. 2016. Sensitivity of marine protected area network connectivity to atmospheric variability Author for correspondence :

Fox, H. E., C. S. Soltanoff, M. B. Mascia, K. M. Haisfield, A. V. Lombana, C. R. Pyke, and L. Wood. 2012. Explaining global patterns and trends in marine protected area (MPA) development. Marine Policy 36:1131-1138.

Gaines, S. D., C. White, M. H. Carr, and S. R. Palumbi. 2010. Designing marine reserve networks for both conservation and fisheries management. Proceedings of the National Academy of Sciences of the United States of America 107:18286-18293.

Gallacher, J., N. Simmonds, H. Fellowes, N. Brown, N. Gill, W. Clark, C. Biggs, and L. D. Rodwell. 2016. Evaluating the success of a marine protected area: A systematic review approach. Journal of Environmental Management 183:280-293.

Geldmann, J., L. Coad, M. D. Barnes, I. D. Craigie, S. Woodley, A. Balmford, T. M. Brooks, M. Hockings, K. Knights, M. B. Mascia, L. McRae, and N. D. Burgess. 2018. A global analysis of management capacity and ecological outcomes in terrestrial protected areas. Conservation Letters 11:1-10.

Giakoumi, S., J. Mcgowan, M. Mills, and M. Beger. 2018. Revisiting "Success" and "Failure" of Marine Protected Areas: A Conservation Scientist Perspective. Frontiers in Marine Science 5.

Gill, D. A., M. B. Mascia, G. N. Ahmadia, L. Glew, S. E. Lester, M. Barnes, I. Craigie, R. D. Gates, G. Guannel, P. J. Mumby, H. Thomas, and S. Whitmee. 2017. Capacity shortfalls hinder the performance of marine protected areas globally. Nature Publishing Group 543:665-669.

Government of Canada. 2014. British Columbia Marine Protected Area Network Strategy. Government of Canada. 
Halpern, B. S., S. E. Lester, and K. L. McLeod. 2010. Placing marine protected areas onto the ecosystem-based management seascape. Proceedings of the National Academy of Sciences of the United States of America 107:18312-7.

Hopkins, C. R., D. M. Bailey, and T. Potts. 2016. Scotland's Marine Protected Area network: Reviewing progress towards achieving commitments for marine conservation. Marine Policy 71:44-53.

Hoyt, E. 2008. Marine protected areas. Pages 688-697 in W. Perrin, B. Würsig, and J. Thewissen, editors. Encyclopedia of Marine Mammals. 2nd edn. Academic Press: San Diego.

IUCN-WCPA. 2008. Establishing Resilient Marine Protected Area Networks - Making It Happen. Washington, D.C.: IUCN World Commission on Protected Areas (IUCN-WCPA), National Oceanic and Atmospheric Adminstration and The Nature Conservancy. Washington, D.C.: IUCN World Commission on Protected Areas (IUCN-WCPA), National Oceanic and Atmospheric Adminstration and The Nature Conservancy.

Johnson, D., J. Ardron, D. Billett, T. Hooper, T. Mullier, P. Chaniotis, B. Ponge, and E. Corcoran. 2014. When is a marine protected area network ecologically coherent? A case study from the North-east Atlantic. Aquatic Conservation: Marine and Freshwater Ecosystems 24:44-58.

Kalinkat, G., J. S. Cabral, W. Darwall, G. F. Ficetola, J. L. Fisher, D. P. Giling, M. P. Gosselin, H. P. Grossart, S. C. Jähnig, J. M. Jeschke, K. Knopf, S. Larsen, G. Onandia, M. Pätzig, W. C. Saul, G. Singer, E. Sperfeld, and I. Jarić. 2017. Flagship umbrella species needed for the conservation of overlooked aquatic biodiversity. Conservation Biology 31:481-485.

Keller, B. D., D. F. Gleason, E. McLeod, C. M. Woodley, S. Airamé, B. D. Causey, A. M. Friedlander, R. Grober-Dunsmore, J. E. Johnson, S. L. Miller, and R. S. Steneck. 2009. Climate change, coral reef ecosystems, and management options for marine protected areas. Environmental Management 44:1069-1088.

Klein, C. J., a Chan, L. Kircher, a J. Cundiff, N. Gardner, Y. Hrovat, a Scholz, B. E. Kendall, and S. Airamé. 2008. Striking a balance between biodiversity conservation and socioeconomic viability in the design of marine protected areas. Conservation biology : the journal of the Society for Conservation Biology 22:691-700.

Krueck, N. C., G. N. Ahmadia, A. Green, G. P. Jones, H. P. Possingham, C. Riginos, E. A. Treml, and P. J. Mumby. 2017. Incorporating larval dispersal into MPA design for both conservation and fisheries. Ecological Applications 27:925-941. 
Leary, B. C. O., N. C. Ban, M. Fernandez, A. M. Friedlander, P. García-borboroglu, Y. Golbuu, P. Guidetti, J. M. Harris, P. Julie, T. I. M. Langlois, J. Douglas, E. K. Pikitch, R. H. Richmond, and C. M. Roberts. 2018. Addressing Criticisms of Large-Scale Marine Protected Areas:359-370.

Marine Scotland. 2013. FEAST. http://www.marine.scotland.gov.uk/feast/.

Marine Scotland. 2014. 2014 Consultation on the Management of Inshore Special Areas of Conservation and Marine Protected Areas. Priortisation.

Marine Scotland. 2017. Scottish Marine Protected Areas (MPA) Monitoring Strategy.

McLeod, E., R. Salm, A. Green, and J. Almany. 2009. Designing marine protected area networks to address the impacts of climate change. Frontiers in Ecology and the Environment 7:362-370.

Mora, C., S. Andrèfouët, M. J. Costello, C. Kranenburg, A. Rollo, J. Veron, K. J. Gaston, and R. a Myers. 2006. Coral reefs and the global network of Marine Protected Areas. Science 312:1750-1751.

OSPAR. 2007. Guidance to assess the effectiveness of management of OSPAR MPAs: a self-assessment scorecard. (Reference number: 2007-5).

OSPAR Commission. 2006. Guidance on developing an ecologically coherent network of OSPAR Marine Protected Areas.

Pajaro, M. G., M. E. Mulrennan, J. Alder, and A. C. J. Vincent. 2010. Developing MPA Effectiveness Indicators: Comparison Within and Across Stakeholder Groups and Communities. Coastal Management 38:122-143.

Pautz, H., O. Tozan, and P. Bradley (Eds). 2019. On Target for 2030? An independent snapshot review of Scotland's progress against the United Nations Sustainable Development Goals.

Pomeroy, R. S., L. M. Watson, J. E. Parks, and G. A. Cid. 2005. How is your MPA doing? A methodology for evaluating the management effectiveness of marine protected areas. Ocean \& Coastal Management 48:485-502.

Pyhälä, A., J. Eklund, M. McBride, and C. Cabeza. 2019. Managers' perceptions of protected area outcomes in Madagascar highlight the need for species monitoring and knowledge transfer. Conservation Science and Policy.

Rees, S. E., N. L. Foster, O. Langmead, S. Pittman, and D. E. Johnson. 2018. Defining the qualitative elements of Aichi Biodiversity Target 11 with regard to the marine and coastal environment in order to strengthen global efforts for marine biodiversity conservation outlined in the United Nations Sustainable Development Goal 14. Marine Policy 93:241-250. 
Roberts, K. E., R. S. Valkan, and C. N. Cook. 2018. Measuring progress in marine protection : A new set of metrics to evaluate the strength of marine protected area networks. Biological Conservation 219:20-27.

Sala, E., J. Lubchenco, K. Grorud-Colvert, C. Novelli, C. Roberts, and U. R. Sumaila. 2018. Assessing real progress towards effective ocean protection. Marine Policy 91:11-13.

Scottish Government. 2011a. A Strategy for Marine Nature Conservation in Scotland's Seas. Available from

http://www.scotland.gov.uk/Topics/marine/marine-environment/Conservationstrategy/marin econstrategy.

Scottish Government. 2011b. Marine Protected Areas in Scotland's Seas: Guidelines on the selection of MPAs and the development of the MPA network. Available from http://www.scotland.gov.uk/Topics/marine/marine environment/mpanetwork/mpaguidelines.

Smith, J., M. Patterson, A. H.M., and J. Ardron. 2009. Criteria and Tools for Designing Ecologically Sound Marine Protected Area Networks in Canada's Marine Regions. WWF-Canada.

Staub, F., and M. E. Hatziolos. 2004. Score Card to Assess Progress in Achieving Management effectiveness goals for Marine Protected Areas. Washington, DC: World Bank.

Woodcock, P., B. C. O. Leary, M. J. Kaiser, and A. S. Pullin. 2016. Your evidence or mine ? Systematic evaluation of reviews of marine protected area effectiveness:668-681.

Wu, W., S. Yan, R. Feng, D. Song, and X. Chen. 2015. Ocean \& Coastal Management Development of an environmental performance indicator framework to evaluate management effectiveness for Jiaozhou Bay Coastal Wetland Special Marine Protected Area, Qingdao, China. Ocean and Coastal Management 142:71-89.

Zupan, M., F. Bulleri, J. Evans, S. Fraschetti, P. Guidetti, A. Garcia-rubies, M. Sostres, V. Asnaghi, A. Caro, S. Deudero, R. Goñi, G. Guarnieri, F. Guilhaumon, D. Kersting, A. Kokkali, C. Kruschel, V. Macic, L. Mangialajo, S. Mallol, E. Macpherson, A. Panucci, M. Radolovic, M. Ramdani, P. J. Schembri, A. Terlizzi, E. Villa, and J. Claudet. 2018. How good is your marine protected area at curbing threats ? Biological Conservation 221:237-245. 


\section{Appendix A.}

Each Nature Conservation Marine Protected Areas (ncMPA) designation order for all 31 designated ncMPAs was reviewed (available from Marine Scotland website (Marine Scotland 2014)). The Loch Carrron Emergency MPA was discounted from further analysis as this site was not part of the original ncMPA selection process guided by the OSPAR ecological principles. The designated features of each MPA, the number of designated features of each MPA and the conservation objectives for those designated features was extracted from the designation orders. The type of feature was categorised in line with the designation order (e.g. mobile species, habitat etc.). The location classification of each MPA (inshore/offshore) was determined using the Scottish Government website. The origin of each ncMPA (e.g. new area, area expanded from existing protected area site) was extracted from Scottish Natural Heritage Advice to the Scottish Government (SNH 2012).

The OSPAR Threatened and Declining list (OSPAR 2008) and the Scottish Priority Marine Features (PMF) list (SNH 2014, Tyler-Walters et al. 2016) were compared against the designated features of the ncMPAs (Table A1). Search Features for MPAs and other features (that are not PMFs) but are designated features were included in the analysis of how many PMFs are designated features. How the PMFs, search features and designated features are represented and replicated within the ncMPA network was determined by analysis of MPA process documentation (SNH 2012), and cross referencing with the ncMPA designation orders. 
Table A.1 Representation of Scottish Priority Marine Features (PMFs) within the ncMPA network

\begin{tabular}{|c|c|c|c|c|}
\hline Priority Marine Feature (PMF) & Type & $\begin{array}{l}\text { OSPAR } \\
\text { Threatened/ } \\
\text { Declining List }\end{array}$ & $\begin{array}{l}\text { MPA Search } \\
\text { Feature }^{1}\end{array}$ & $\begin{array}{l}\text { MPA se } \\
\text { feature } \\
\text { represe } \\
\text { protect } \\
\text { measu }\end{array}$ \\
\hline Blue Mussel beds & Seabed habitat & Yes & Yes & $\mathrm{SAC} / \mathrm{Fis}$ \\
\hline Burrowed mud & Seabed habitat & Yes & Yes & SAC \\
\hline Carbonate mounds communities & Seabed habitat & Yes & Yes & $\mathrm{SAC} / \mathrm{Fis}$ \\
\hline Cold water coral reefs & Seabed habitat & Yes & No & $\mathrm{n} / \mathrm{a}$ \\
\hline Coral gardens & Seabed habitat & Yes & Yes & $\mathrm{SAC} / \mathrm{Fis}$ \\
\hline Deep sea sponge aggregations & Seabed habitat & Yes & Yes & - \\
\hline Flame shell beds & Seabed habitat & No & Yes & - \\
\hline Horse mussel beds & Seabed habitat & Yes & Yes & SAC \\
\hline Inshore deep mud with burrowing heart urchins & Seabed habitat & No & Yes & $\mathrm{SAC} / \mathrm{Fis}$ \\
\hline Intertidal mudflats & Seabed habitat & No & No & $\mathrm{n} / \mathrm{a}$ \\
\hline Kelp and seaweed communities on sublittoral sediment & Seabed habitat & No & Yes & SAC \\
\hline Kelp beds & Seabed habitat & No & No & $\mathrm{n} / \mathrm{a}$ \\
\hline Low or variable salinity habitats & Seabed habitat & No & Yes & SAC/Fis \\
\hline Maerl beds & Seabed habitat & Yes & Yes & SAC \\
\hline Maerl or coarse shell gravel with burrowing sea cucumbers & Seabed habitat & No & Yes & SAC \\
\hline Native oysters & Seabed habitat & Yes & Yes & - \\
\hline Northern sea fan and sponge communities & Seabed habitat & No & Yes & SAC \\
\hline Offshore deep sea muds & Seabed habitat & No & Yes & SAC \\
\hline Offshore subtidal sands and gravels & Seabed habitat & No & Yes & SAC \\
\hline Seagrass beds & Seabed habitat & Yes & Yes & SAC \\
\hline Sea loch egg wrack beds & Seabed habitat & No & Yes & $\mathrm{SAC} / \mathrm{Fis}$ \\
\hline Seamount communities & Seabed habitat & No & Yes & - \\
\hline Serpulid aggregations & Seabed habitat & No & No & - \\
\hline Submarine structures made by leaking gases & Seabed habitat & No & No & $\mathrm{n} / \mathrm{a}$ \\
\hline Tide-swept algal communities & Seabed habitat & No & Yes & $\mathrm{SAC} / \mathrm{Fis}$ \\
\hline $\begin{array}{l}\text { Tide swept coarse sands with burrowing bivalves. } \\
\text { (sometimes referred to as Shallow) }\end{array}$ & Seabed habitat & No & Yes & - \\
\hline Burrowing sea anemone & $\begin{array}{l}\text { Low or limited } \\
\text { mobility }\end{array}$ & No & Yes & - \\
\hline Pink sea fingers & $\begin{array}{l}\text { Low or limited } \\
\text { mobility }\end{array}$ & No & No & $\mathrm{n} / \mathrm{a}$ \\
\hline White cluster anemone & $\begin{array}{l}\text { Low or limited } \\
\text { mobility }\end{array}$ & No & No & ncMPA \\
\hline Northern feather star & $\begin{array}{l}\text { Low or limited } \\
\text { mobility }\end{array}$ & No & Yes & SAC \\
\hline Fan mussel & $\begin{array}{l}\text { Low or limited } \\
\text { mobility }\end{array}$ & No & Yes & Fisheri \\
\hline Heart cockle & $\begin{array}{l}\text { Low or limited } \\
\text { mobility }\end{array}$ & No & Yes & - \\
\hline
\end{tabular}




\begin{tabular}{|c|c|c|c|c|}
\hline Ocean quahog & $\begin{array}{l}\text { Low or limited } \\
\text { mobility }\end{array}$ & Yes & Yes & SAC \\
\hline European spiny lobster & Mobile species & No & Yes & SAC/Fis \\
\hline Eel & Mobile species & Yes & No & $\mathrm{n} / \mathrm{a}$ \\
\hline Atlantic salmon & Mobile species & Yes & No & $\mathrm{n} / \mathrm{a}$ \\
\hline European river lamprey & Mobile species & No & No & $\mathrm{n} / \mathrm{a}$ \\
\hline Sea lamprey & Mobile species & Yes & No & $\mathrm{n} / \mathrm{a}$ \\
\hline Sea trout & Mobile species & No & No & $\mathrm{n} / \mathrm{a}$ \\
\hline Sparling & Mobile species & No & No & $\mathrm{n} / \mathrm{a}$ \\
\hline Anglerfish & Mobile species & No & No & $\mathrm{n} / \mathrm{a}$ \\
\hline Atlantic halibut & Mobile species & No & No & $\mathrm{n} / \mathrm{a}$ \\
\hline Atlantic herring & Mobile species & No & No & $\mathrm{n} / \mathrm{a}$ \\
\hline Atlantic mackerel & Mobile species & No & No & $\mathrm{n} / \mathrm{a}$ \\
\hline Black scabbardfish & Mobile species & No & No & $\mathrm{n} / \mathrm{a}$ \\
\hline Blue ling & Mobile species & No & Yes & $\begin{array}{l}\text { Area ba } \\
\text { measur }\end{array}$ \\
\hline Blue whiting & Mobile species & No & No & $\mathrm{n} / \mathrm{a}$ \\
\hline Cod & Mobile species & Yes & No & $\mathrm{n} / \mathrm{a}$ \\
\hline Greenland halibut & Mobile species & No & No & $\mathrm{n} / \mathrm{a}$ \\
\hline Horse mackerel & Mobile species & No & No & $\mathrm{n} / \mathrm{a}$ \\
\hline Ling & Mobile species & No & No & $\mathrm{n} / \mathrm{a}$ \\
\hline Norway pout & Mobile species & No & No & $\mathrm{n} / \mathrm{a}$ \\
\hline Orange roughy & Mobile species & Yes & Yes & $\begin{array}{l}\text { Non are } \\
\text { fisherie }\end{array}$ \\
\hline Round-nose grenadier & Mobile species & No & No & $\mathrm{n} / \mathrm{a}$ \\
\hline Saithe & Mobile species & No & No & $\mathrm{n} / \mathrm{a}$ \\
\hline Sandeels & Mobile species & No & Yes & $\mathrm{SAC} / \mathrm{Fis}$ \\
\hline Sand goby & Mobile species & No & No & $\mathrm{n} / \mathrm{a}$ \\
\hline Whiting & Mobile species & No & No & $\mathrm{n} / \mathrm{a}$ \\
\hline Basking shark & Mobile species & Yes & Yes & - \\
\hline Common skate & Mobile species & Yes & Yes & - \\
\hline Leafscale gulper shark & Mobile species & Yes & No & $\mathrm{n} / \mathrm{a}$ \\
\hline Porbeagle shark & Mobile species & Yes & No & $\mathrm{n} / \mathrm{a}$ \\
\hline Portuguese dogfish & Mobile species & Yes & No & $\mathrm{n} / \mathrm{a}$ \\
\hline Sandy ray & Mobile species & No & No & $\mathrm{n} / \mathrm{a}$ \\
\hline Spiny dogfish & Mobile species & No & No & $\mathrm{n} / \mathrm{a}$ \\
\hline Atlantic white sided dolphin & Mobile species & No & No & $\mathrm{n} / \mathrm{a}$ \\
\hline Bottlenose dolphin & Mobile species & No & No & $\mathrm{n} / \mathrm{a}$ \\
\hline Fin whale & Mobile species & No & No & $\mathrm{n} / \mathrm{a}$ \\
\hline Harbour porpoise & Mobile species & Yes & No & $\mathrm{n} / \mathrm{a}$ \\
\hline Killer whale & Mobile species & No & No & $\mathrm{n} / \mathrm{a}$ \\
\hline Long finned pilot whale & Mobile species & No & No & $\mathrm{n} / \mathrm{a}$ \\
\hline
\end{tabular}




\begin{tabular}{|l|l|l|l|l}
\hline Minke whale & Mobile species & No & Yes & - \\
\hline Northern bottlenose whale & Mobile species & No & No & $\mathrm{n} / \mathrm{a}$ \\
\hline Risso's dolphin & Mobile species & No & Yes & - \\
\hline Short- beaked common dolphin & Mobile species & No & No & $\mathrm{n} / \mathrm{a}$ \\
\hline Sowerby's beaked whale & Mobile species & No & No & $\mathrm{n} / \mathrm{a}$ \\
\hline Sperm whale & Mobile species & No & No & $\mathrm{n} / \mathrm{a}$ \\
\hline White beaked dolphin & Mobile species & No & Yes & \\
\hline Harbour/ common seal & & & No & $\mathrm{n} / \mathrm{a}$ \\
\hline Grey seal & Mobile species & No & No & $\mathrm{n} / \mathrm{a}$ \\
\hline Otter & Mobile species & No & No & $\mathrm{n} / \mathrm{a}$ \\
\hline
\end{tabular}

${ }^{1}$ MPA search features are features of Scottish biodiversity importance for which MPAs were considered an appropriate protection measure and for which sufficient data were likely to be available.

${ }^{2}$ Existing network consists of protected sites including Special Areas of Conservation (SACS) and Special Protection Areas (SPAs), designated under the Habitats Directive and the Birds Directive, and SSSIs. 
Table A.2 Additional features within the Nature Conservation Marine Protected Areas (ncMPA) network not classified as Priority Marine Features (PMFs)

\begin{tabular}{|l|l|}
\hline $\begin{array}{l}\text { Additional MPA Search } \\
\text { Features }\end{array}$ & $\begin{array}{l}\text { OSPAR Threatened/ } \\
\text { Declining List }\end{array}$ \\
\hline Black guillemot & No \\
\hline Continental slope & No \\
\hline Fronts & No \\
\hline Seamounts & Yes \\
\hline Shelf banks and mounds & No \\
\hline Shelf deeps & No \\
\hline Other Designated Features \\
\hline Circalittoral sand and coarse sediment communities \\
\hline Marine Geomorphology of the Scottish Shelf Seabed \\
\hline Quaternary of Scotland \\
\hline Sublittoral mud and mixed sediment \\
\hline Circalittoral muddy sand communities \\
\hline Seabed Fluid and Gas Seep - pockmarks \\
\hline Submarine Mass Movement \\
\hline Marine Geomorphology of the Scottish Deep Ocean Seabed \\
\hline Polygonal fault systems \\
\hline Cenozoic structures of the Atlantic Margin \\
\hline
\end{tabular}

Table A.3 Designated features within each designated Nature Conservation (ncMPA) site.

\begin{tabular}{|c|c|c|c|}
\hline ncMPA & Designated Feature & Type of Feature & Con \\
\hline Clyde Sea Sill MPA & Black guillemot & Mobile species & Con \\
\hline Clyde Sea Sill MPA & $\begin{array}{l}\text { Circalittoral and offshore sand and } \\
\text { course sediment communities }\end{array}$ & Habitat & Con \\
\hline Clyde Sea Sill MPA & Fronts & Large scale feature & Con \\
\hline Clyde Sea Sill MPA & $\begin{array}{l}\text { Marine Geomorphology of the } \\
\text { Scottish Shelf Seabed - sand wave } \\
\text { fields, sand ribbon fields, and sand } \\
\text { banks }\end{array}$ & Geomorphological & Con \\
\hline East Caithness Cliffs MPA & Black guillemot & Mobile species & Con \\
\hline Fetlar to Haroldswick MPA & Black guillemot & Mobile species & Con \\
\hline Fetlar to Haroldswick MPA & $\begin{array}{l}\text { Circalittoral sand and coarse sediment } \\
\text { communities }\end{array}$ & Habitat & \\
\hline
\end{tabular}




\begin{tabular}{|c|c|c|c|}
\hline Fetlar to Haroldswick MPA & Horse mussel beds & Habitat & $\overline{\text { Cons }}$ \\
\hline Fetlar to Haroldswick MPA & $\begin{array}{l}\text { Kelp and seaweed communities on } \\
\text { sublittoral sediment }\end{array}$ & Habitat & \\
\hline Fetlar to Haroldswick MPA & Maerl beds & Habitat & Cons \\
\hline Fetlar to Haroldswick MPA & $\begin{array}{l}\text { Shallow tide-swept coarse sands with } \\
\text { burrowing bivalves }\end{array}$ & Habitat & \\
\hline Fetlar to Haroldswick MPA & $\begin{array}{l}\text { Marine geomorphology of the Scottish } \\
\text { shelf seabed }\end{array}$ & Geomorphological & \\
\hline Loch Creran MPA & Flame Shell Beds & Habitat & Cons \\
\hline Loch Creran MPA & Quaternary of Scotland & Geomorphological & \\
\hline Loch Sunart MPA & Flame Shell Beds & Habitat & Cons \\
\hline Loch Sunart MPA & $\begin{array}{l}\text { Northern feather star aggregations on } \\
\text { mixed substrata }\end{array}$ & Low or limited mobility species & \\
\hline Loch Sunart MPA & Serpulid aggregations & Habitat & \\
\hline Loch Sunart to the Sound of Jura MPA & Common skate & Mobile species & Cons \\
\hline Loch Sunart to the Sound of Jura MPA & Quaternary of Scotland & Geomorphological & Cons \\
\hline Loch Sween MPA & Burrowed mud & Habitat & Cons \\
\hline Loch Sween MPA & Maerl beds & Habitat & Cons \\
\hline Loch Sween MPA & Native oysters & Habitat & \\
\hline Loch Sween MPA & $\begin{array}{l}\text { Sublittoral mud and mixed sediment } \\
\text { communities }\end{array}$ & Habitat & \\
\hline Lochs Duich, Long and Alsh MPA & Burrowed mud & Habitat & Cons \\
\hline Lochs Duich, Long and Alsh MPA & Flame Shell Beds & Habitat & \\
\hline Monach Isles MPA & Black guillemot & Mobile species & Cons \\
\hline Monach Isles MPA & $\begin{array}{l}\text { Marine geomorphology of the Scottish } \\
\text { shelf seabed }\end{array}$ & Geomorphological & \\
\hline Monach Isles MPA & $\begin{array}{l}\text { Quaternary of Scotland - landscape of } \\
\text { areal glacial scour }\end{array}$ & Geomorphological & \\
\hline Mousa to Boddam MPA & Sandeels & Mobile species & \\
\hline Mousa to Boddam MPA & $\begin{array}{l}\text { Marine geomorphology of the Scottish } \\
\text { shelf seabed }\end{array}$ & Geomorphological & \\
\hline Noss Head MPA & Horse mussel beds & Habitat & \\
\hline Papa Westray MPA & Black guillemot & Mobile species & \\
\hline Papa Westray MPA & $\begin{array}{l}\text { Marine geomorphology of the Scottish } \\
\text { shelf seabed - sand wave field }\end{array}$ & Geomorphological & \\
\hline Small Isles MPA & Black guillemot & Mobile species & \\
\hline Small Isles MPA & Burrowed mud & Habitat & \\
\hline Small Isles MPA & $\begin{array}{l}\text { Circalittoral sand and mud } \\
\text { communities }\end{array}$ & Habitat & \\
\hline Small Isles MPA & Fan mussel aggregations & Habitat & Cons \\
\hline Small Isles MPA & Horse mussel beds & Habitat & \\
\hline Small Isles MPA & $\begin{array}{l}\text { Northern feather star aggregations on } \\
\text { mixed substrata }\end{array}$ & Low or limited mobility species & \\
\hline Small Isles MPA & $\begin{array}{l}\text { Northern sea fan and sponge } \\
\text { communities }\end{array}$ & Habitat & Cons \\
\hline Small Isles MPA & Shelf deeps & Large scale feature & Cons \\
\hline Small Isles MPA & White cluster anemones & Low or limited mobility species & \\
\hline
\end{tabular}




\begin{tabular}{|c|c|c|c|}
\hline Small Isles MPA & $\begin{array}{l}\text { Quaternary of Scotland - glaciated } \\
\text { channels/troughs, glacial lineations, } \\
\text { meltwater channels, moraines, } \\
\text { streamlined bedforms }\end{array}$ & Geomorphological & Con \\
\hline South Arran MPA & Burrowed mud & Habitat & Co \\
\hline South Arran MPA & $\begin{array}{l}\text { Kelp and seaweed communities on } \\
\text { sublittoral sediment }\end{array}$ & Habitat & Con \\
\hline South Arran MPA & Maerl beds & Habitat & $\operatorname{Re}$ \\
\hline South Arran MPA & $\begin{array}{l}\text { Maerl or coarse shell gravel with } \\
\text { burrowing sea cucumbers }\end{array}$ & Habitat & \\
\hline South Arran MPA & Ocean quahog aggregations & Low or limited mobility species & Co \\
\hline South Arran MPA & Seagrass beds & Habitat & Con \\
\hline South Arran MPA & $\begin{array}{l}\text { Shallow tide-swept coarse sands with } \\
\text { burrowing bivalves }\end{array}$ & Habitat & \\
\hline Upper Loch Fyne and Loch Goil MPA & Burrowed mud & Habitat & $\mathrm{Co}$ \\
\hline Upper Loch Fyne and Loch Goil MPA & Flame Shell Beds & Habitat & $\operatorname{Re}$ \\
\hline Upper Loch Fyne and Loch Goil MPA & Horse mussel beds & Habitat & Co \\
\hline Upper Loch Fyne and Loch Goil MPA & Ocean quahog aggregations & Low or limited mobility species & Cor \\
\hline Upper Loch Fyne and Loch Goil MPA & $\begin{array}{l}\text { Sublittoral mud and specific mixed } \\
\text { sediment communities }\end{array}$ & Habitat & \\
\hline Wester Ross MPA & Burrowed mud & Habitat & $\mathrm{Co}$ \\
\hline Wester Ross MPA & Circalittoral muddy sand communities & Habitat & $\mathrm{Co}$ \\
\hline Wester Ross MPA & Flame Shell Beds & Habitat & $\operatorname{Re}$ \\
\hline Wester Ross MPA & $\begin{array}{l}\text { Kelp and seaweed communities on } \\
\text { sublittoral sediment }\end{array}$ & Habitat & \\
\hline Wester Ross MPA & Maerl beds & Habitat & $\operatorname{Re}$ \\
\hline Wester Ross MPA & $\begin{array}{l}\text { Maerl or coarse shell gravel with } \\
\text { burrowing sea cucumbers }\end{array}$ & Habitat & \\
\hline Wester Ross MPA & $\begin{array}{l}\text { Northern feather star aggregations on } \\
\text { mixed substrata }\end{array}$ & Low or limited mobility species & $\mathrm{Co}$ \\
\hline Wester Ross MPA & $\begin{array}{l}\text { Marine geomorphology of the Scottish } \\
\text { shelf seabed - banks of unknown } \\
\text { substrate }\end{array}$ & Geomorphological & Con \\
\hline Wester Ross MPA & $\begin{array}{l}\text { Quaternary of Scotland - glaciated } \\
\text { channels/troughs, megascale glacial } \\
\text { lineations, moraines }\end{array}$ & Geomorphological & CoI \\
\hline Wester Ross MPA & $\begin{array}{l}\text { Seabed fluid and gas seep - } \\
\text { pockmarks }\end{array}$ & Geomorphological & \\
\hline Wester Ross MPA & $\begin{array}{l}\text { Submarine Mass Movement - slide } \\
\text { scars }\end{array}$ & Geomorphological & \\
\hline Wyre and Rousay Sounds MPA & $\begin{array}{l}\text { Kelp and seaweed communities on } \\
\text { sublittoral sediment }\end{array}$ & Habitat & Co \\
\hline Wyre and Rousay Sounds MPA & Maerl beds & Habitat & Con \\
\hline Wyre and Rousay Sounds MPA & $\begin{array}{l}\text { Marine geomorphology of the Scottish } \\
\text { shelf seabed }\end{array}$ & Geomorphological & Con \\
\hline Central Fladen & Burrowed mud & Habitat & Cons \\
\hline Central Fladen & $\begin{array}{l}\text { Quaternary of Scotland - sub glacial } \\
\text { tunnel valley }\end{array}$ & Geomorphological & Con \\
\hline East of Gannet and Montrose Fields & Ocean quahog aggregations & Low or limited mobility species & Con \\
\hline East of Gannet and Montrose Fields & Offshore subtidal sands and gravels & Habitat & Con \\
\hline
\end{tabular}




\begin{tabular}{|c|c|c|c|}
\hline East of Gannet and Montrose Fields & Offshore deep sea muds & Habitat & Cons \\
\hline Faroe-Shetland Sponge Belt & Deep sea sponge aggregations & Habitat & Cons \\
\hline Faroe-Shetland Sponge Belt & Offshore subtidal sands and gravels & Habitat & Cons \\
\hline Faroe-Shetland Sponge Belt & Ocean quahog aggregations & Low or limited mobility species & Cor \\
\hline Faroe-Shetland Sponge Belt & Continental slope & Large scale feature & \\
\hline Faroe-Shetland Sponge Belt & $\begin{array}{l}\text { Quaternary of Scotland - continental } \\
\text { slope channels; iceberg ploughmark } \\
\text { fields, prograding wedges }\end{array}$ & Geomorphological & \\
\hline Faroe-Shetland Sponge Belt & $\begin{array}{l}\text { Submarine Mass Movement - slide } \\
\text { deposits }\end{array}$ & Geomorphological & \\
\hline Faroe-Shetland Sponge Belt & $\begin{array}{l}\text { Marine Geomorphology of the } \\
\text { Scottish Deep Ocean Seabed - sand } \\
\text { wave fields, sediment wave fields }\end{array}$ & Geomorphological & \\
\hline Faroe-Shetland Sponge Belt & $\begin{array}{l}\text { Marine Geomorphology of the } \\
\text { Scottish Shelf Seabed - sand bank, } \\
\text { sand wave fields, sediment wave fields }\end{array}$ & Geomorphological & \\
\hline Firth of Forth Banks Complex & Ocean quahog aggregations & Low or limited mobility species & Cons \\
\hline Firth of Forth Banks Complex & Offshore subtidal sands and gravels & Habitat & Cons \\
\hline Firth of Forth Banks Complex & Shelf banks and mounds & Large scale feature & \\
\hline Firth of Forth Banks Complex & Quaternary of Scotland - moraines & Geomorphological & \\
\hline Geike Slide and Hebridean Slope & Burrowed mud & Habitat & \\
\hline Geike Slide and Hebridean Slope & Offshore subtidal sands and gravels & Habitat & Cons \\
\hline Geike Slide and Hebridean Slope & Continental slope & Large scale feature & Cor \\
\hline Geike Slide and Hebridean Slope & $\begin{array}{l}\text { Submarine Mass Movement - slide } \\
\text { deposits, slide scars }\end{array}$ & Geomorphological & \\
\hline Geike Slide and Hebridean Slope & Offshore deep sea muds & Habitat & Cons \\
\hline Hatton-Rockall Basin & Deep sea sponge aggregations & Habitat & \\
\hline Hatton-Rockall Basin & Offshore deep sea muds & Habitat & Cons \\
\hline Hatton-Rockall Basin & $\begin{array}{l}\text { Marine Geomorphology of the } \\
\text { Scottish Deep Ocean Seabed - } \\
\text { sediment drifts }\end{array}$ & Geomorphological & Cons \\
\hline Hatton-Rockall Basin & Polygonal fault systems & Geomorphological & Cons \\
\hline North-east Faroe Shetland Channel & Deep sea sponge aggregations & Habitat & \\
\hline North-east Faroe Shetland Channel & Offshore deep sea muds & Habitat & \\
\hline North-east Faroe Shetland Channel & Offshore subtidal sands and gravels & Habitat & \\
\hline North-east Faroe Shetland Channel & Continental slope & Large scale feature & Cons \\
\hline North-east Faroe Shetland Channel & $\begin{array}{l}\text { Quaternary of Scotland - prograding } \\
\text { wedge }\end{array}$ & Geomorphological & \\
\hline North-east Faroe Shetland Channel & $\begin{array}{l}\text { Submarine Mass Movement - slide } \\
\text { deposits }\end{array}$ & Geomorphological & \\
\hline North-east Faroe Shetland Channel & $\begin{array}{l}\text { Marine Geomorphology of the } \\
\text { Scottish Deep Ocean Seabed - } \\
\text { contourite sand/silt; }\end{array}$ & Geomorphological & \\
\hline North-east Faroe Shetland Channel & $\begin{array}{l}\text { Cenozoic Structures of the Atlantic } \\
\text { Margin - mud diapirs }\end{array}$ & Geological & \\
\hline North-west Orkney & Sandeels & Mobile species & \\
\hline North-west Orkney & $\begin{array}{l}\text { Marine Geomorphology of the } \\
\text { Scottish Shelf Seabed - sand bank, } \\
\text { sand wave fields, sediment wave fields }\end{array}$ & Geomorphological & \\
\hline
\end{tabular}




\begin{tabular}{|c|c|c|c|}
\hline Norwegian Sediment Boundary Plain & Ocean quahog aggregations & Low or limited mobility species & Cons \\
\hline Norwegian Sediment Boundary Plain & $\begin{array}{l}\text { Offshore subtidal sands and gravels } \\
\text { representing sediment types suitable } \\
\text { for Ocean quahog colonisation }\end{array}$ & Habitat & \\
\hline Rosemary Bank Seamount & Deep sea sponge aggregations & Habitat & Cons \\
\hline Rosemary Bank Seamount & Seamount communities & Habitat & \\
\hline Rosemary Bank Seamount & Seamounts & Large scale feature & \\
\hline Rosemary Bank Seamount & $\begin{array}{l}\text { Quaternary of Scotland - iceberg } \\
\text { ploughmark field }\end{array}$ & Geomorphological & \\
\hline Rosemary Bank Seamount & $\begin{array}{l}\text { Submarine Mass Movement - slide } \\
\text { scars }\end{array}$ & Geomorphological & \\
\hline Rosemary Bank Seamount & $\begin{array}{l}\text { Marine Geomorphology of the } \\
\text { Scottish Deep Ocean Seabed - scour } \\
\text { moats, sediment drifts, sediment } \\
\text { wave fields }\end{array}$ & Geomorphological & \\
\hline Rosemary Bank Seamount & $\begin{array}{l}\text { Cenozoic Structures of the Atlantic } \\
\text { Margin - Rosemary Bank Seamount }\end{array}$ & Geological & \\
\hline $\begin{array}{l}\text { The Barra Fan and Hebrides Terrace } \\
\text { Seamount }\end{array}$ & Burrowed mud & Habitat & \\
\hline $\begin{array}{l}\text { The Barra Fan and Hebrides Terrace } \\
\text { Seamount }\end{array}$ & Offshore subtidal sands and gravels & Habitat & \\
\hline $\begin{array}{l}\text { The Barra Fan and Hebrides Terrace } \\
\text { Seamount }\end{array}$ & Offshore deep sea muds & Habitat & \\
\hline $\begin{array}{l}\text { The Barra Fan and Hebrides Terrace } \\
\text { Seamount }\end{array}$ & Orange roughy & Mobile species & \\
\hline $\begin{array}{l}\text { The Barra Fan and Hebrides Terrace } \\
\text { Seamount }\end{array}$ & Seamount communities & Habitat & \\
\hline $\begin{array}{l}\text { The Barra Fan and Hebrides Terrace } \\
\text { Seamount }\end{array}$ & Continental slope & Large scale feature & \\
\hline $\begin{array}{l}\text { The Barra Fan and Hebrides Terrace } \\
\text { Seamount }\end{array}$ & Seamounts & Large scale feature & \\
\hline $\begin{array}{l}\text { The Barra Fan and Hebrides Terrace } \\
\text { Seamount }\end{array}$ & $\begin{array}{l}\text { Quaternary of Scotland - iceberg } \\
\text { ploughmark field, prograding wedges }\end{array}$ & Geomorphological & \\
\hline $\begin{array}{l}\text { The Barra Fan and Hebrides Terrace } \\
\text { Seamount }\end{array}$ & $\begin{array}{l}\text { Submarine Mass Movement - } \\
\text { continental slope turbidite canyons, } \\
\text { slide deposits }\end{array}$ & Geomorphological & \\
\hline $\begin{array}{l}\text { The Barra Fan and Hebrides Terrace } \\
\text { Seamount }\end{array}$ & $\begin{array}{l}\text { Marine Geomorphology of the } \\
\text { Scottish Deep Ocean Seabed - scour } \\
\text { moat }\end{array}$ & Geomorphological & \\
\hline $\begin{array}{l}\text { The Barra Fan and Hebrides Terrace } \\
\text { Seamount }\end{array}$ & $\begin{array}{l}\text { Cenozoic Structures of the Atlantic } \\
\text { Margin - continental slope, Hebrides } \\
\text { Terrace Seamount }\end{array}$ & Geological & \\
\hline Turbot Bank & Sandeels & Mobile species & Cons \\
\hline West Shetland Shelf & Offshore subtidal sands and gravels & Habitat & \\
\hline
\end{tabular}


Table A.4 Nature Conservation Marine Protected Area (ncMPA) site origin (e.g. enhancement to existing protected area, enhancement to other area-based measures, new area, $3^{\text {rd }}$ party proposal, a "Least Damaged/More Natural) as extracted from SNH (2012)

\begin{tabular}{|c|c|c|c|c|c|}
\hline $\begin{array}{l}\text { Nature Conservation Marine } \\
\text { Protected Area (ncMPA) }\end{array}$ & Location & Origin $^{1}$ & New Area & $\begin{array}{l}\text { Least } \\
\text { Damaged } \\
\text { More Natural } \\
\text { (LDMN) }\end{array}$ & $\begin{array}{l}\text { Existing } \\
\text { Protecte } \\
\text { Area }\end{array}$ \\
\hline Clyde Sea Sill MPA & Inshore & Other area based & 0 & 0 & 0 \\
\hline East Caithness Cliffs MPA & Inshore & Existing Protected Area & 0 & 0 & 1 \\
\hline Fetlar to Haroldswick MPA & Inshore & Existing Protected Area & 0 & 0 & 1 \\
\hline Loch Creran MPA & Inshore & Existing Protected Area & 0 & 0 & 1 \\
\hline Loch Sunart MPA & Inshore & $\begin{array}{l}\text { Existing Protected } \\
\text { Area; 3rd Party }\end{array}$ & 0 & 0 & 1 \\
\hline Loch Sunart to the Sound of Jura MPA & Inshore & New area; 3rd Party & 1 & 0 & 0 \\
\hline Loch Sween MPA & Inshore & $\begin{array}{l}\text { Other area based; } \\
\text { LDMN; 3rd Party }\end{array}$ & 0 & 1 & 0 \\
\hline Lochs Duich, Long and Alsh MPA & Inshore & $\begin{array}{l}\text { Existing Protected } \\
\text { Area; LDMN }\end{array}$ & 0 & 1 & 1 \\
\hline Monach Isles MPA & Inshore & Existing Protected Area & 0 & 0 & 1 \\
\hline Mousa to Boddam MPA & Inshore & Existing Protected Area & 0 & 0 & 1 \\
\hline Noss Head MPA & Inshore & Other area based & 0 & 0 & 0 \\
\hline Papa Westray MPA & Inshore & Existing Protected Area & 0 & 0 & 1 \\
\hline Small Isles MPA & Inshore & Existing Protected Area & 0 & 0 & 1 \\
\hline South Arran MPA & Inshore & Other area based* & 0 & 0 & 0 \\
\hline Upper Loch Fyne and Loch Goil MPA & Inshore & Other area based & 0 & 0 & 0 \\
\hline Wester Ross MPA & Inshore & Other area based & 0 & 0 & 0 \\
\hline Wyre and Rousay Sounds MPA & Inshore & New area & 1 & 0 & 0 \\
\hline Central Fladen & Offshore & New area & 1 & 0 & 0 \\
\hline East of Gannet and Montrose Fields & Offshore & LDMN & 0 & 1 & 0 \\
\hline Faroe-Shetland Sponge Belt & Offshore & LDMN & 0 & 1 & 0 \\
\hline Firth of Forth Banks Complex & Offshore & $\begin{array}{l}\text { LDMN; Other area } \\
\text { based }\end{array}$ & 0 & 1 & 0 \\
\hline Geike Slide and Hebridean Slope & Offshore & $\begin{array}{l}\text { Other area based; } \\
\text { LDMN }\end{array}$ & 0 & 1 & 0 \\
\hline Hatton-Rockall Basin & Offshore & LDMN & 0 & 1 & 0 \\
\hline North-east Faroe Shetland Channel & Offshore & LDMN & 0 & 1 & 0 \\
\hline North-west Orkney & Offshore & New area & 1 & 0 & 0 \\
\hline Norwegian Sediment Boundary Plain & Offshore & LDMN & 0 & 1 & 0 \\
\hline Rosemary Bank Seamount & Offshore & $\begin{array}{l}\text { Other area based; } \\
\text { LDMN }\end{array}$ & 0 & 1 & 0 \\
\hline $\begin{array}{l}\text { The Barra Fan and Hebrides Terrace } \\
\text { Seamount }\end{array}$ & Offshore & $\begin{array}{l}\text { Other area based; } \\
\text { LDMN }\end{array}$ & 0 & 1 & 0 \\
\hline Turbot Bank & Offshore & New area & 1 & 0 & 0 \\
\hline West Shetland Shelf & Offshore & Other area based & 0 & 0 & 0 \\
\hline Counts of Site by Origin ${ }^{2}$ & & & 5 & 11 & 9 \\
\hline
\end{tabular}


*Not considered an enhancement because of the difference in scale between the fisheries restriction and the resultant MPA proposal

${ }^{1}$ Origin includes the following definitions: existing protected area - includes area that is already designated as protected under different legislation; new area - no existing protective measures are in place; other area based - includes area that is protected under different spatial measures e.g. fisheries closures; LDMN - Least Damaged/More Natural - an area that is considered to have minimal human disturbance; $3^{\text {rd }}$ party proposal - locations proposed by other groups not including SNH, JNCC and Marine Scotland

${ }^{2}$ Includes counts of areas that may have more than one origin

Table A.5 Status of management measures for designated sites in the Scottish ncMPA network including: awaiting inshore management measures; managed under Fisheries Order; managed under Marine Conservation Order and awaiting EU formal negotiation

\begin{tabular}{|c|c|c|c|}
\hline MPA & Code & Location & Management Status \\
\hline Clyde Sea Sill MPA & CSS & Inshore & $\begin{array}{l}\text { Awaiting inshore management } \\
\text { measures }\end{array}$ \\
\hline East Caithness Cliffs MPA & ECC & Inshore & $\begin{array}{l}\text { Awaiting inshore management } \\
\text { measures }\end{array}$ \\
\hline Fetlar to Haroldswick MPA & FTH & Inshore & $\begin{array}{l}\text { Awaiting inshore management } \\
\text { measures }\end{array}$ \\
\hline Loch Creran MPA & LCR & Inshore & Fisheries Order \\
\hline Loch Sunart MPA & LSU & Inshore & Fisheries Order \\
\hline Loch Sunart to the Sound of Jura MPA & SJU & Inshore & Marine Conservation Order \\
\hline Loch Sween MPA & LSW & Inshore & Fisheries Order \\
\hline Lochs Duich, Long and Alsh MPA & DLA & Inshore & Fisheries Order \\
\hline Monach Isles MPA & $\mathrm{MOI}$ & Inshore & $\begin{array}{l}\text { Awaiting inshore management } \\
\text { measures }\end{array}$ \\
\hline Mousa to Boddam MPA & MTB & Inshore & $\begin{array}{l}\text { Awaiting inshore management } \\
\text { measures }\end{array}$ \\
\hline Noss Head MPA & $\mathrm{NOH}$ & Inshore & Fisheries Order \\
\hline Papa Westray MPA & PWJ & Inshore & $\begin{array}{l}\text { Awaiting inshore management } \\
\text { measures }\end{array}$ \\
\hline Small Isles MPA & SMI & Inshore & $\begin{array}{l}\text { Reconsulting on Marine } \\
\text { Conservation Order }\end{array}$ \\
\hline South Arran MPA & ARR & Inshore & Marine Conservation Order \\
\hline Upper Loch Fyne and Loch Goil MPA & LFG & Inshore & Fisheries Order \\
\hline Wester Ross MPA & WER & Inshore & Marine Conservation Order \\
\hline Wyre and Rousay Sounds MPA & WYR & Inshore & Fisheries Order \\
\hline Central Fladen & CFL & Offshore & Awaiting EU formal negotiation \\
\hline East of Gannet and Montrose Fields & EGM & Offshore & Awaiting EU formal negotiation \\
\hline Faroe-Shetland Sponge Belt & FSS & Offshore & Awaiting EU formal negotiation \\
\hline Firth of Forth Banks Complex & FOF & Offshore & Awaiting EU formal negotiation \\
\hline Geike Slide and Hebridean Slope & GSH & Offshore & Awaiting EU formal negotiation \\
\hline Hatton-Rockall Basin & HRB & Offshore & Awaiting EU formal negotiation \\
\hline North-east Faroe Shetland Channel & NEF & Offshore & Awaiting EU formal negotiation \\
\hline North-west Orkney & NOW & Offshore & Awaiting EU formal negotiation \\
\hline Norwegian Sediment Boundary Plain & NSP & Offshore & Awaiting EU formal negotiation \\
\hline
\end{tabular}




\begin{tabular}{|l|l|l|l|}
\hline Rosemary Bank Seamount & RBS & Offshore & Awaiting EU formal negotiation \\
\hline $\begin{array}{l}\text { The Barra Fan and Hebrides Terrace } \\
\text { Seamount }\end{array}$ & BHT & Offshore & Awaiting EU formal negotiation \\
\hline Turbot Bank & TBB & Offshore & Awaiting EU formal negotiation \\
\hline West Shetland Shelf & WSS & Offshore & Awaiting EU formal negotiation \\
\hline
\end{tabular}




\section{Appendix A. References}

Marine Scotland. 2014.

https://www2.gov.scot/Topics/marine/marine-environment/mpanetwork/developing/DesignationO rders.

OSPAR. 2008. OSPAR List of Threatened and/or Declining Species and Habitats. Reference Number: 2008-6.

SNH. 2012. Advice to the Scottish Government on the selection of Nature Conservation Marine Protected Areas ( MPAs ) for the development of the Scottish MPA network. Commissioned report 547. Available from http://www.snh.org.uk/pdfs/publications/commissioned_reports.

SNH. 2014. Priority Marine Features in Scotland's Seas.

Tyler-Walters, H., B. James, M. Carruthers, C. Wilding, O. Durkin, C. Lacey, E. Philpott, L. Adamas, P. D. Chaniotis, P. T. V. Wilkes, R. Seeley, M. Neilly, J. Dargie, and O. T. Crawford-Avis. 2016. Descriptions of Scottish Priority Marine Features (PMFs). Scottish Natural Heritage Commissioned Report No. 406. 